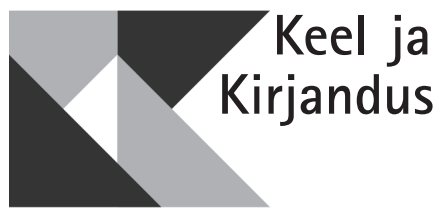

\title{
TÜVITEKSTI MÕISTEST
}

\author{
ARNE MERILAI
}

$\mathrm{T}$ uumteose - alusteose, baasteose, lähteteose või kui välmime, seminaali mõiste on võrdlevas kirjandusteaduses möödapääsmatu. Akadeemilises inglise keeles käibivaid väljendeid core text või seminal work on eesti keeles paaril viimasel kümnendil hakatud tähistama-tõlkima sõnaga tüvitekst. Kui algselt toimus see üsna metafoorselt ja kombates, juuri-oksi ja toekaid tüvesid kiites, vahel ka veel säilinud irooniavarjundiga, siis nüüd kasutatakse seda kujundlikku liitsõna juba juurdunud terminina, mis ei vaja pikalt seletamist. Veel enam: tõlgendavast metakirjandusest on tüviteksti käsitus levinud ka ühiskondlikku tarvitusse, mis tõendab, et tekstuaalsuse mõtestamisel on nii selletaolist mõistet kui ka sõna-terminit igapäevaselt tarvis. Inimeste ühiselus juurduv ühismeel (ingl common sense) tajub seda nähtust olulisena ja loob sellest kõnelemiseks ühise praktika.

Kogu ilmakera humanitaaria teoorialembusele vaatamata ei torka aga eriti silma tüviteksti mõistele keskenduvat üldistavat teooriat, kuigi mõistekasutus ise on küllalt sagedane. Väljapaistvaima viite pakub vahest rahvusvahelise ulatusega tüvitekstide assotsiatsioon Ameerikas, mille eesmärgid on aga pigem rakenduslik-pedagoogilised, mitte filosoofilised. ${ }^{1}$ Valdavalt

${ }^{1}$ Ühenduse kodulehelt loeme, et tüvitekstide ja nende õpetamise assotsiatsioon ACTC (The Association for Core Texts and Courses) toetab isikuid, pakub foorumeid ja arendab initsiatiivi, mis edendab ja tugevdab maailmaklassika või kultuuriliselt oluliste tekstide ühist ning lõimitud uurimist. ACTC on rahvusvaheline ja professionaalne organisatsioon, mis soosib õppejõude ning administraatoreid, kes on pühendunud tervikliku liberaalse hariduse ülesehitamisele, mis on rajatud tüvitekstide kursustele. Vt http://www.coretexts. org (27. IX 2017). 
keskendutakse assotsiatsioonis konkreetsetele klassikateostele kui tüvitekstidele, mitte tüvitekstuaalsuse üle teoretiseerimisele. Laias ilmas leidub küll lademes arutelusid kaanoni mõistmise - kujundamise ja lammutamise kohta, kuid see on ikkagi vana ja uue hea klassika käsitamise diskurss, mille tähendusväli on tüviteksti omast kitsam: iga klassikateos on ühtlasi ka tüvitekst, kuid iga tüvitekst ei kuulu veel klassikakaanonisse.

Eesti kohalik tüvitekstihuvi tundub muu ilmaga võrreldes omajagu intensiivsem: kas on see mööduv moeasi või sügavam iseduseküsimus, aga oleme tõepoolest harjunud oma armsatest alustekstidest lugu pidama ja möönma, et olulisemad neist loovad koguni rahvust. Nagu Joseph Smithi kuldkiri mormoonidele, nõnda ka Kreutzwaldi lugulaul eestlastele: tärkava kogukonna vaimne rajaja. Heideggerlik olemise luulelise kehtestamise idee oleks siin kahtlemata üheks seletusjõuliseks teoreetilise mõtestuse lähtepunktiks (vt Heidegger 1954; Merilai 2007).

\section{Tüviteksti mõiste A-stsenaarium}

1980. aastatel asus Linnart Mäll välja arendama oma kontseptsiooni inimkonna kultuuriliste mõttesuundade baastekstidest (vt Ude 1988). Peagi hakkas ta neid nimetama humanistlikeks baastekstideks, mis on aluseks budismile, konfutsianismile, kristlusele ja hinduismile. Saanud 1994. aastal viimaks vanemteaduriks, korraldas Mäll Antslas ja Tartus rahvusvahelise seminari „Ida klassikaliste tekstide interpreteerimise kunst” (vt The Art of... 1994), millest edenevalt avati baastekstide uurimiseks 1997. aastal ka sihtfinantseeritav teadusteema (vt ka Mäll 2000a, 2000b). 2008. aastal sai ta selle tegevuse eest Eesti Vabariigi teaduspreemia. Mälli kohta ütleb tema õpilane Märt Läänemets: „Üle poole tema tõlgetest moodustavad nn inimkonna baastekstid, s.t tekstid, mis väga pika aja vältel on mingi religiooni või kultuuriareaali elus mänginud üliolulist rolli, väga suure generatiivse väega tekstid” (Läänemets 1995: 741).

Linnart Mäll kirjutab, et ta „peab viimase paari aastatuhande ajalookulu suurimateks mõjutajateks humanistlikke baastekste”, mis kujundasid välja „uue ühiskondliku mõõtme” - kultuuri (Mäll 2000a: 5):

Hoolimata nende suurest mõjust ei ole humanistlikke baastekste tegelikult kuigi palju. Neid loodi või need ilmusid või tekkisid või kujunesid [---] Vana Maailma mitmes piirkonnas kindlal ajalooperioodil. [---]

Sõna 'baastekst' viitab muidugi teosele, mis on olnud aluseks uutele tekstidele; seega on tegemist teosega, mis aja kulgedes on toiminud tekstigeneraatorina. Tõelisel baastekstil on võime tekitada määramatu aja vältel ükskõik kui suurel hulgal uusi tekste ja need ei pea sugugi olema kirjalikult fikseeritud, vaid võivad ja enamikul juhul esinevadki kas suulise kõne või arutluse kujul või isegi mõttelise tegevusena [---].

Humanistlikul baastekstil on eriline suunitlus [---], mida iseloomustab ühelt poolt inimese kui niisuguse (teisisõnu, kui liigi ja kui üksikisiku) ülendamine olemasolu keskseks ja määravaks nähtuseks, teiselt poolt aga niisuguste „inimlike” omaduste rõhutamine inimestevahelises suhtluses, nagu väärikus, inimarmastus, kaastunne, vägivallatus, vastutustunne, kohusetundlikkus, aupaklikkus jt. 
Kuigi iga humanistlik baastekst on kujunenud oma kindla kultuuri kontekstis, mille mõju on avaldunud selle sisus ja vormis nii suures ulatuses, et esmapilgul võib tunduda raske, kui mitte üldse võimatu neid ühise nimetaja alla viia, on sarnasusi ja ühiseid jooni selleks siiski piisavalt [---]. (Mäll 2000a: $5-6)$

Mälli tõlgenduses ühendab inimlikke alustekste väljakujunemine arenenud kultuurikeskkonnas, mille tunnusteks on kirjakeel, ühiskondlik hierarhia, valdav religioosne või mütoloogiline mõttemaailm koos kallakuga olemasoleva ümbermõtestamisele. Neil tekstidel on nimelised autorid ja väljakujunenud traditsioon, neis esitatakse kindlat Õpetust erakordse, ent inimliku Õpetaja suu läbi: nende õpetuste määravaimaks küljeks on humaansus - inimlikkus ja inimsus, olemasolu mõte ja uueks saamise teekond, vaimne arenemine ja sügavam mõistmine, isiksuse täiustumine (Mäll 2000a: 6-11). Mälli fookus on ilmne: teda köitvad humanistlikud baastekstid on väike, täiendiga piiritletud alaosa baastekstide kui nähtuse palju avaramast hulgast.

Baasteksti asemel sai siiski laiema leviku osaliseks küllap suupärasem omasõna tüvitekst, mille tõi meie akadeemilisse keelepruuki Jaan Undusk Felix Oinase artiklikogumiku „Surematu Kalevipoeg” saateartiklis „Rahvaluuleteksti lõppematus" (Undusk 1994). Nagu Mällgi, mõtles ka Undusk suurelt ja tühja-tähja välistavalt: tüvitekst on eeskätt „rahvust loov tekst”, „rahvuse sakraalne narratiiv”, mille „üksikud laused ja eriti motiivid ning tegelasstruktuurid on rahvuskehasse sööbinud sedavõrd tugevasti, et neid eemaldades lammutaksime rahvuslikku psüühikat ennast”. Nõnda ei väsi meie kirjandusteadlased tsiteerimast Unduski tüviteksti tüviteksti kohta:

Hoolimata teravast kriitikast, mis „Kalevipoega” algusest peale saatis, sai temast eesti rahvustunde ideoloogiline telg, rahvusliku ajaloomütoloogia, süvakujutelmade ja mõttemallide ärataja, omamoodi vastupandamatu teos, mis tasapindse argipäeva all avas vanad maa-alused kambrid.

[---] ta sai - ja osalt vastu tahtmistki - rahvusliku eneseanalüüsi ja -hinnangu käsiraamatuks, või kes teab, võimalik, et isegi rahvuse sakraalseks narratiiviks, mis neelas oma sümboleisse kogu eestlaste loo algusest otsani. [---] Kui „Kalevipojas” on kultuurilist eklektikat, siis on see eestlase enda ajalooline eklektilisus.

Et „Kalevipoeg” kõige kiuste on eestlaste kui rahvuse tüvitekst (mida ei ole ei nn. autentne rahvaluule, ei Jakobsoni isamaakõned ega Tammsaare „Tõde ja õigus”), siis toob iga tõsisem eepose mõtestamise katse enesega kaasa avastusretke eestluse aluspõhja. Just seetõttu võiksid „Kalevipoja”-uuringud märgistada rahvusteaduslikke pulsilööke. (Undusk 1994: 148-149)²

${ }^{2}$ Huvitava paralleeli pakuvad soomlased: nende rahvuseepos on struktureerinud me hõimlaste vaimulaadi. Nimelt mõned aastad tagasi riputati Soome Kirjanduse Seltsi kodulehele eestikeelne artikkel „Kalevala kaasaegses Soomes”, millest võis lugeda: „,Kalevala” on jätnud oma kustumatu jälje nii paljudele elualadele Soomes, et seda on sageli isegi raske märgata. Eepose mõju meie kultuuri ja igapäevase elu-olu erinevates sektorites on olnud pidev. Kõige paremini on see hoomatav mitmesugustes nimedes. Linnaosad, tänavad, ettevõtted ja tooted ammendavad pidevalt ainest rahvuseepose rikkalikust ja eriilmelisest varasalvest. „Kalevalast” on saanud täiesti ainulaadne kaubamärk maailmas.” Vt neba.finlit.fi/kalevala/index.php?m=116\&s=185\&l=7 (27. IX 2017). 
Tüviteksti mõistet on Undusk kasutanud hiljemgi. Artiklis „Kolm võimalust kirjutada eestlaste ajalugu: Merkel - Jakobson - Hurt" ütleb ta, siiski kerge reservatsiooniga, et „Kalevipoeg” on „rahvuse omamoodi tüvitekst” (Undusk 1997: 730). Samuti ei välista ta muidki eeldatavaid tüvitekste nende erakordsuses (,ilmselt ka üldise vooluga rohkem kaasa minnes”, nagu arvas käesoleva artikli eelretsensent). Nii ütleb ta Henriku Liivimaa kroonika kohta, et see „on Balti ajaloo tüvitekst ja eestlaste alusnarratiiv, mille tõlgendamisest sõltub kõik muu” (Undusk 2008), või et Ristikivi „Hingede öö” „on mälukaotuskirjanduse tüvitekst eesti keeles" (Undusk 2012: 1459).

Kui Mälli aspekt kaldub rohkem tulevikkuloova, uusi tekste genereeriva maatriksi suunas, siis Unduskit näib rohkem huvitavat kultuuriline koondumine, vaimne kontsentraat, mille järgnev mõjukus pigem väljub tekstuaalsusest. Nagu Mälli, nii ka Unduski puhul tuleb muidugi tähele panna kitsendavat täiendit ja vahet teha hierarhial: humanistlik baastekst või rahvuslik tüvitekst kui ainukordne tüvitekst, sest loomulikult ei salata tüvitekstide fenomenaalset paljusust.

Kahe mõtleja eksklusiivset tõlgendust kaldutakse vahel elliptiliselt mõistma, ilma nonde tähtsate, välistavate epiteetideta humanistlik ja rahvuslik. Sellises piiritlemises võib aga näha olulist lisandust tuumteksti tavamõistele. Tiina Kirss on esile toonud, et ingliskeelne termin core text ei hõlma eestikeelse tüviteksti üldkultuurilist, rahvust (resp. kultuuri) loova teksti süvendatud tähendust (Laak 2013: 194), mistõttu Kirss eristaks tüvi-, alus- ja põhitekste, reserveerides esimese Unduski mõjul pigem rahvust loovate tekstide tähistamiseks, vastandades nõnda ainulisi tekste mitmuslikele:

Tüviteksti latentne orgaanilisuse-metafoorsus (tüvel on juured, ajab võrseid jne) on võluv, kuid ka eksitav. Unduski tüvitekstimääratluselt laenan oma käsitluse tarvis eelkõige rõhuasetuse, et tüvitekst on tüvitekst peaasjalikult rahvuse, mitte kirjandusliku kaanoni loomise seisukohast. (Kirss 2010: 39)

Niisiis just viimase, rahvusliku tüviteksti kohta käib Unduski „elitaarne” programm, mida võiks siinkohal A-stsenaariumiks nimetada. See ettekujutus hõlmab ühtlasi Mälli loodud süsteemi. A-stsenaarium on kantud eliotliku klassika määratluse vaimust, mis kahandab vastavate teoste hulka nõudlikult miinimumini. Thomas Stearns Elioti eksklusiivses tõlgenduses suutis kõige klassikalisema teose nõudeid täita teatavasti ainuüksi Vergiliuse „Aeneis”, mis vastas Rooma rahva ja epohhi saatusele. Pärast oli Dantel hea oma teejuhi õlgadele tõusta, et jumaliku komöödiani küünitada. Aga ka Homerosel, Shakespeare'il või Goethel olid mõned tarvilikud tunnused Elioti meelest siiski Vergiliusest kahvatumad, mistõttu nemad olid küll mõne mööndusega suured klassikud, ent mitte piisavalt ehk absoluutselt nagu uhkes üksinduses kõrguv ületamatu roomlane. Nimelt nõudis Eliot klassikalt neljakordset täiuslikkust: ajaloolise vaimu ja kultiveeritud kommete küpsust, traditsioonidele ja haritusele tuginevat keeleküpsust ning ühisstiili täiust. Nende põhitunnustega pidi kaasnema ka rahvusülene universaalsus (vt Eliot 1997).

Nõnda näeme, et ka Undusk ei luba isegi rahvaluule regivärssi, ei Tammsaaret ega ka rahvuspoliitilist diskurssi rahvusliku tüviteksti magusale marjamaale. Loomulikult on see nii poolt- kui ka vastuargumenteeritav. Selge see, et Jakob Tamme poolt koolijütsidele ette loetud „Kalevipoeg” 
ja „Kalevala” kujundasid tugevasti noort Tammsaaret, aga mitte kausaalselt tagurpidi (kuigi meie teadvuses suudavad hilisemad nähtused siiski ka varasemate tähendust mõjutada). ${ }^{3}$ Ent teisalt ei ole ajas hilisem „Tõe ja õiguse" epopöa sõnakunstiteos, mis kuidagi kahvatuks me rahvuseepose kõrval, pigem võib arvata ristioksa - seda muidugi melanhoolse mõtterütmilise esteetika, mitte vabaduseaate alusel. Moderniseeruv rahvus oli Tammsaare ajaks juba oluliselt välja kujundatud, kiikamaks ümbrust me ideoloogilise hiiu õlgadelt.

Unduskile oponeeriv Tiit Hennoste on aga koguni radikaalsem ja arvab karmilt, et eestlastel ei olegi veel tüviteksti, et tüvitekstirahvana oleme õieti alles kujunemas, seega meie teadvust kujundab pigem hajus fragmentaarium kui sidusalt struktureeriv tekst. Niisiis me alles kosume nagu Kõrboja imik keset punaseid valuvaid marju (või nagu Kalevala Maarja palukamarjast poeg) - hääs lootuses. Kui Hennostet uskuda, siis me alles hüppame rahvusliku tüviteksti poole:

Minu arvates ei ole eesti kultuuri põhi kirjandus. Eesti kultuuri põhjaks on tekst ja laiemalt tekstide maailm.

Vahest kuulsaim tekstirahvas on juudid. Neil on oma tüvitekst ja selle kommentaarium. Aga oluline on, et tüvitekst ei ole midagi algusest peale valmis olevat. Tüvitekst on pöördepunkt. Enne teda on killud, millest tüvitekst kokku pannakse. Pärast teda on laiendused ja kommentaarid.

Undusk tahtis eestlaste jaoks välja tuua samasuguse tüviteksti „Kalevipoja” näol. Minu arust ei ole „Kalevipoeg” tüvitekst. Veel enam, eesti tüvitekst on siiani midagi pooleliolevat. Suuremalt jaolt on meil üksnes tüvilaused või -lõigud. (Tee tööd, siis... Parem suutäis soolast... Kes kannatab...) Eesti (tüvi)tekst tuleks alles lausetest kokku korjata. [---]

Aga nagu eespool ütlesin, ei toetu eesti kultuur minu arvates ainsale aluspõhjale ega kirjandusele, vaid tekstile. Samas aga puudub eesti kultuuris seniajani tüvitekst. See tuleks alles kokku korjata, et saada tulevikule tugev alus. (Hennoste 2011: 1146, 1148)

Ka „Kalevipoja”-tõlgendaja Marin Laak kaldub unduskiliku visiooni poole, eelistades pihustatud kasutamisele pigem ainulise suurnarratiivi tähistamist: tüvitekst kui alus- ehk prototekst lugematutele järglastele ehk metatekstidele (Laak 2013: 192). Kui teos rohkeid siirdeid ei anna, sealjuures eriti transmediaalseid „tõlkeid” teistesse kunstiliikidesse, siis Laak tüviteksti mõistet targu ei kasutaks, vaid piirduks lihtsalt ütlusega „hea eesti kirjandus, klassika”. Ta eristab mõiste tarvitamises nelja tasandit: 1) tüvitekst kui „tuumne rahvusteadvuse säsi” („Kalevipoeg”) - küllap siis too päris tüvitekst; 2) mõjukas transmediaalsete siirete alustekst („Kevade”, „Tõde ja õigus"), 3) lihtsalt kirjanduslooline klassika (Faehlmanni muistendid, Underi sonetid) või 4) argikeelne kasutus kui „mingi olulise/viljaka nähtuse sünonüüm”, mis „on saanud üldmõisteks, mida kuuleb sageli isegi massimeedia kanalites" (Laak 2013: 193). Niisiis pigem antikliimaks tuumsest tsentrist hajusa ääremaa poole:

${ }^{3}$ Tammsaare emotsionaalseks tüvitekstiks oli pigem Juhan Liivi „Vari”. 
Rõhutagem, et selle kolmanda tüviteksti mõistevälja puhul pole tegemist kirjandusliku alusteksti viljaka „tõlkimisega” teistesse kunstikeeltesse, vaid võib-olla lihtsalt läbi aegade hea eesti kirjandusega, klassikaga. Tüviteksti mõiste sellise rakendamise puhul oleksin Tiit Hennostega pigem nõus, et mõiste laienemine suurele tekstikorpusele lammutab kogu selle idee ära. (Laak 2013: 193)

\section{Tüviteksti mõiste B-stsenaarium}

Tüviteksti mõiste üldisem käsitus hõlmab demokraatlikult väga laia paletti, astmelist hierarhiat kas välistades või välistamata. Nii on Tiina Kirss käsitlenud August Kitzbergi memuaare kui üht „eesti autobiograafilise traditsiooni tüvitekstidest" (Kirss 2010: 39). Samale ideele, käsitleda eesti kirjanduse teoseid seminaalsuse erinevatest aspektidest, toetuvad ka vastavad kursused Tartu Ülikooli kirjanduse ja teatriteaduse osakonnas. Kirss kirjutab:

Mõiste tüvitekst kätkeb nii võimalusteküllust, modelleerivat ainulaadsust kui ka traditsiooni rajavat toimet, struktureeritud ning struktureerivale traditsioonile läve ning mõõdu andmist. Omaelulookirjutusele ülekantuna on tüvitekst seega jutustamisvõimaluste, jututüüpide ja autobiograafiliste impulsside kompendium, varasalv, millest hilisemad memuaaride kirjutajad laenavad ning valivad, mille järgi nad end mõõdavad ja hindavad, otseste vihjetena jälgi jätmata. [---]

Lõppkokkuvõttes võiksime Kitzbergi „Tuuletallajat” autobiograafiliseks tüvitekstiks pidada eelkõige selle iseendast kaugemale vaatavate kultuurilooliste intentsioonide tõttu, püüdlustes suhestada oma elulugu hõlmavamate narratiivide, suuremate lugudega. (Kirss 2010: 39, 51)

Mõistemänguline ja laia publikut inspireeriv on olnud aga Rein Veidemanni propaganda nii õppejõu kui ka kultuuriajakirjanikuna. Võib arvata, et just tema tunderõhulistest korduvkasutustest paljudel avalikel foorumitel ja massimeedias levis tüviteksti idee ning sõna ühiskonna üldkasutusse. Mööndes eneselegi üllatuseks oma edukat misjonitööd ühe sõna „rändama minemisel” ja „käibenime staatuse omandamisel”, kommenteerib Veidemann:

Mina söandan pidada end selle „tüviteksti”, kui Unduskil veel metafoorina ehkki aluseks tema käsitlus „Etüüdid tekstist” - kirjanduskultuuriliseks, täpsemalt, kirjandussemiootiliseks edasiarendajaks, selle terminus technicus'ena, aga ka kirjandus- ja kultuuriprotsessi kaanoni „ehituskivina”, ühe või teise kultuuri (tegelikult) „selgroolülidena”.

Selliselt läheb „tüvitekst” käibele järgmistes minu käsitlustes: „Kultuur rahvusliku müüdi kujundajana”, „Eesti müüt ja Noor-Eesti”, „Märkmeid „Kevadest” kui müüdist”, „Eesti müüt ja Jaan Kross” - kõik esseed ilmunud esmakordselt raamatus „Ajavahe”, ilmumiseelselt ette kantud aga mingitel konverentsidel või sümpoosionidel. Esimesena mainitud artiklis veel implitsiitselt „rahvusliku narrateemina” (sümbolsõnad, jutustused, lausungid), järgnevates juba „tüviteksti” mõistet kasutades. Viimases essees näiteks tees: 
Eriliselt mõjukas oma rohke resonantsiga näikse olnud Veidemanni ettekanne „Laulupidu kui eesti kultuuri tüvitekst” 1999. aasta 1.-2. juulil rahvusraamatukogus toimunud „Eestluse elujõu kongressil”, mis ilmus seejärel esseena Sirbis (Veidemann 1999a) ja mitut puhku ning versioonis veel järgnevalt (Veidemann 2000a, 2001, 2004, 2006: 73-77, 2011, 2014). Sakraalse (šamanistliku, puhastava, religioonilaadse), vaba ja kunstipäraselt performatiivse rahvusliku riituse lähteidee - laulupidu kui osadustundega kogudust loov tundeline diskurss, mil on tüvitekstiline iseloom - sähvatas muidugi juba enne kongressi, jälgitavalt Eesti Päevalehe nupus („Püha toiming laulupidu”, 2. VII 1999), mille kultuurilisa Arkaadia asutaja ja toimetaja oli Veidemann. Ta meenutab:

Arvan, et sest peale algas ka meedias „tüviteksti” eskalatsioon kõige erinevamates vormides. Samal aastal alustasin ka Tallinna Ülikoolis kursust „Eesti kultuuri (klassikalised) tüvitekstid”. („Klassikaline” käskis panna epiteediks õppekava kureerinud kolleeg Marek Tamm, pidades silmas just ajaloolist aspekti ja kaanonit). Järgnevates käsitlustes hakkan aga ka ise varieerima tüviteksti, tuues esile selle sakraliseerituse („Fr. R. Kreutzwaldi „Kalevipoeg” kui eesti kirjanduskultuuri sakraaltekst”), aga ka näiteks niisuguse aspekti nagu memorandumil (memoreerimine + kuulutus; vt „Tuikav tekst”).

O. Lutsu „Kevadet” tüvitekstina käsitlen laiemalt ja süvenenumalt 2008. aasta Akadeemias, taastrükk raamatus „Eksistentsiaalne Eesti” (2010) [---] „Kevade”-artiklis on teost nimetatud samuti nagu Undusk „Kalevipoja” puhul „müütiloovaks tekstiks”. [---]

Muide, aastal 2000 ilmus kogumik „Eesti uue aastatuhande lävel”, seal on mul samuti artikkel „Kultuur XXI sajandi künnisel”. Selles teen juttu „Eesti kultuuri tuumtekstist” (rahvuslik müüt, minapilt), mitte päriselt „tüvitekst”, pigem rahvusteadvusega seotud, aga ikkagi „tekst” - eks see omakorda võimendus.

Jah, tüviteksti emantsipatsioon argikeelde algab sealt! Nii juba siis 17-18 aastat. (e-kiri A. Merilaile 13. II 2017; vt ka Veidemann 2000b, 2003, 2006: 59-72, 121-129, 2010: 94-101)

Eeskätt just Veidemanni käsitusest said lehelugejad aimu, et tüvitekst on kasulik mõiste, mida võib tarvitada mitte ainuüksi kirjanduslike tekstide, vaid üleüldse erinevate diskursside algupära kohta, et see ei ole tingimata ahta mahuga välistav, ainuüksi literatuurne idee. Mõiste levikut võib isegi väiksemat sorti plahvatuseks pidada. On enesestmõistetav, et kirjandusteadlased ja -kriitikud kasutavad massimeedias siin-seal sõna tüvitekst. Kuid huvipakkuv on esile tuua ka teiste vaimusfääride ja üldisema rahvakasutuse või koguni riigiametlikke kihte, kus ilmneb omajagu loomingulisust.

Kõigepealt ei puudu ühistajust ja -praktikast muidugi ainukordse lähteklassika tähendusväli, mistõttu võrguavarustest võib välja noppida kõikvõimalikke eeldatavaid sõna- või mõttekunsti nähtusi, nagu eeposed, rahvaluule,

${ }^{4}$ Mäluvärskenduseks peaks siiski märkima, et Jaan Unduski „Etüüdid tekstist” ei kasuta mitte tüviteksti, vaid tuumteksti sõna ja seda üsna teises, formalistlikus mõttes (vt Undusk 1992). 
mällilikud baastekstid, pühakirjad, maailma- või eesti kirjanduse klassikud ja nende põhiteosed, mida kõike tüvitekstiks nimetatakse ${ }^{5}$ : „Gilgameš”, „Ilias”, „Aeneis”, „Vanem Edda”, Niebelungide saaga, regiluule, dainad, „Kalevala”, „Kalevipoeg”...; „Daodejing”, Laozi, „Dhammapada”, piibel, koraan...; „Jumalik komöödia”, „Don Quijote”, Shakespeare, „Hamlet”, „Faust”, „Kolm musketäri”, „Rohulehed”, „Seitse venda”, Juhan Liiv; „Tõde ja õigus”, „Sada aastat üksildust"...

Ajatu klassika tähistamise kõrval võib aga jälgida mõistevälja avardumist ka piirnevatele aladele nii üldise kaanoni sees kui ka väljas: Läti Henriku ja Christian Kelchi Liivimaa kroonikad kui Eesti ajaloo tüvitekstid; „Mu isamaa on minu arm”, „Libahunt”, „Hõbevalge”, „Felix Ormusson”, „Arthur Valdes”, „Tuulemaa”, „Hingede öö”, „Inimese teekond”, „Muhu monoloogid” ja „Järvesuu poiste brigaad”, „Tühirand” ja „Sügisball”, 101 kirjandusteost Rein Veidemanni tõlgenduses, Paul-Eerik Rummo luule, Viivi Luige romaanid...

Selle kõrval on ergutav kohata ka alternatiivseid mõtteid: „Valliku Annitriloogiat võib pidada meie uuema noortekirjanduse tüvitekstiks”, „Kalev Kesküla luule allusioonid eesti tüvitekstidele”, „Aili Helmi küüditatute ja vangistatute omaeluloolisuse tüvitekst”, „ulmekirjanduse tüvitekstid”, „Arthur Gordon Pymi” lugu kui „protoulmekirjanduse üks tüvitekst”, „Jüri Ehlvesti koguretseptsiooni kontekstis eendub teatava tüvitekstina Kajar Pruuli artikkel „Ebakindluse kiituseks"”, „on hulk eesti tüvitekste, mis on tegelikult murdekeelsed”, „,Rongisõidust” sai meie perekonnas kõigi lapsepõlvi ühendav ja mällu sööbinud tüvitekst”, „Samal aastal ilmus eesti biitproosa tüvitekst Peeter Sauteri romaan „Indigo””, „Kui vaadata turutõrkeid kultuuriministeeriumi poole pealt, siis need on eelkõige kõik see, mis on seotud eestikeelsete tüvitekstide loomisega, nende levitamise ja säilitamisega”...

Toogem tüüpilisemad või erilisemad näited ilmestamaks seda, et ühiskondlik tüvitekstitaju on väljunud puhtkirjanduslikult väljalt ja hakanud levima ka teaduse, sotsiaalia, teiste kunstiliikide alale.

Teadused: humanitaarteaduste ainekursused „Antiikfilosoofia tüvitekstid”, „Keskaja filosoofia tüvitekstid”, „Uusaja filosoofia tüvitekstid”; Freudi tüvitekst „Unenägude seletamine”; XX sajandi II poole kirjandusteaduse tüvitekstid; soouuringute tüvitekstid näitavad naist Teisena; Oskar Lutsu „Kevade” kui koolipsühholoogia tüvitekst; „küpsuskirjand on justkui miniatuurne tüvitekst” - „õpilase isiklik tüvitekst”; kooli väärtuskasvatuse alused: tüvitekstid, tüvipersoonid, ankrusümbolid; riiklik õppekava: „Terviklikult käsitletavate teoste valikus on rohkesti klassikat, nn tüvitekste”; „Alfred Koorti essee René Descartes'ist (1937) jaguneb sissejuhatavaks panegüüriliseks osaks ja referatiivseks tüvitekstiks”; „Alustuseks rääkis Kristiina Ross piiblitõlke ajaloost, mis peaks olema kõigi tõlkijate tüvitekstiks”; „Lugu võib olla tüvitekst, mille peale saab iga geopargi piirkonna inimene kirjutada oma loo"...

Socialia: „meie riikluse tüvitekstid”; „üks eesti õiguse tüvitekste on Balti eraseadus”; „Eesti Vabariigi põhiseadus kui meie õiguskorra tüvitekst”; põhiseaduskomisjon: „Eesti Vabariigi põhiseadus on meie elu aluspõhimõtteid sätestav tüvitekst, mis on teiste õigusaktide suhtes ülimuslik”; „Eesti Kultuuri Koja põhialuste tüvitekst peab olema lakooniline”; „poliitilises spektris

${ }^{5}$ Kalendritegija kimbatuse vältimiseks ehk leksikoloogi õigusega jätan näitekataloogi veebiviited andmata, kuivõrd padrik kasvaks üle pea. Enamiku allikaid leiab huviline võrgust hõlpsasti üles, avastades selle kõrval uusi kobaraid. 
rohelisema poole tüvitekste ilmselt ei ilmu"; sotsiaaldemokraatlik manifest kui tüvitekst Sven Mikseri järgi; „1938. aastal välja antud ÜK(b)P lühikursus kujunes Nõukogude kommunistliku ideoloogia tüvitekstiks"; esimese maakultuuriseminari „tüvitekstid olid siis Kaarel Liidaku „Eesti rahvuslik ideoloogia ja maa selle alusena”, Oskar Looritsa „Eestluse elujõud” ja Kalle Elleri „Maarahvast"'....

„Pamela ehk Hüvitatud voorus” kui puritaanide tüvitekst; „Kuid tüvitekstid juhivad inimesed ikka üsna ühes suunas ja sõeluvad isegi paljude jumalate seast välja need, kelle suhtes inimestel on eriline austus”; „Hümnist ja kultuuri tüvitekstidest Soomes ja Eestis”; „Arvestades hr Kiple sõnumi igikestvust ja tüvitekstiks tõusmist, oleks siis tulevastel palveränduritel ja muinsuskaitsjatel lihtsam orienteeruda”; „Kui kasutada kolleeg Rein Veidemanni terminit, siis on looduslikud pühapaigad meie kultuuri üks tüvitekste”; „Mingid teemad, võib-olla sobib neid nimetada ka tänapäeva tüvitekstideks, on ühiskonnas pidevalt arutamisel. [---] Ideaal oleks olnud selliste tüviarutelude ühtekoondamine”; „Kivisildnik on nii raske juhtum, et laseme lugejal ise otsustada, kas tema Õhtulehes ilmunud programmiline kirjutis on lahe iroonia või misogüünia tüvitekst”...

„,Kokaraamat rokib täiega”: „Raamatumüügi edetabelites troonib Evelin Ilvese tüvitekst „Kingitud maitsed”"; „Kapitoidusõprade klubi tüvitekst on Krister Kivi artikkel „Kuidas ma lõpetasin kulutamise toidule”;; „Peeter Oja memuaarides loodud tüvitekstid”; „Kasutasime tüvitekstina „ID-kaardi raamatut”. Võimas impressiivne tekst 64 leheküljel”; „Mõlemad mudelid on peainseneri sõnul Toyota tegelik olemus, tüvitekst, milleta tootja kaotab olulise osa oma kuvandist”; „Tänase päeva Eesti tüvitekstid vähemalt Twitteri järgi on Jaak Aaviksoo võidusambateemaline blogipost „Mina ja sammas” ja Daniel Vaariku reaktsioon”; spordiblogi: „Priidu iga sissekanne on tüvitekst”, see on „kui tüvi, millest hakkavad hargnema igasugused muud tekstid”...

Teater: „Eestlasele paistab teater olevat tüvitekst ja eriti väärtuslik ajas, mis on ebakindel ja kus elust on mängurõõm välja voolamas”; „Mis puutub Toompere eksperimenteerimisse Kivirähi „Rehepapiga”, mitte üksnes omamaise bestselleri, vaid peaaegu et uusaegse rahvuskirjandusliku tüvitekstiga (või, palun, milline teos siis veel võiks säärasele tiitlile pretendeerida?)"; "Tüviteksti lavalepanek on jooksnud puusse”; ballett „Kevade” ainetel - see on „eesti kultuuri keskne teos, võib öelda - tüvitekst”; „Sammumisi ümber tüvitekstide. Eesti teatril on kombeks mitu Krappi korraga”; „,Küüni täitmine” kui tüvitekst. Missugune pealkiri!"...

Film: „Viimne reliikvia” kui eesti filmi tüvitekst; „Filmide püramiidi tipud on tüvitekstid”; „Beavis ja Butthead” kui tüvitekst: „,,South Parki” loojad Trey Parker ja Matt Stone on nimetanud B ja B-d tüvitekstiks või bluusiks"; „Diskussiooni tüvitekst on seriaal „Yes, Minister””; „Kogu horrorižanri, aga eelkõige splätter-komöödia austajate jaoks kujutab „Evil Dead” endast samasugust tüviteksti nagu laulupidu Rein Veidemanni jaoks”; Veidemann: „Kirjanduslikuks tüvitekstiks, millest hargnevad teised tekstid, vormus „Ukuaru” romaan Leida Laiuse filmiga 1974”; kui animeerida, siis aktuaalne on „Juhan Liivi tüvitekst, mis räägib lumest, töötusest ja hoolimisest”; „Eesti film ei ole veel tüvitekst. Parim osa on dokumentaalfilm”; „DVD-plaatidele jõuab 30 palavalt armastatud mängufilmi, millest moodustuv sari koondab endas meie 
kultuuripärandi tähtsamaid tüvitekste mängufilmi valdkonnas”; „Headest filmidest saavad kultuuri tüvitekstid”; „Eesti filmi tüvi”...

Muusika: „Eesti mikroskoopilise popkultuuri tüvitekstid”; „Biitlid kui eesti kultuuri tüvitekst”; „Rein Veidemann kuulutaks Tätte eesti rahvuse tüvitekstiks”; „Ma kavatsen kitsedele laulda ja eesti tüvitekste lugeda”; „Konkreetseks objektiks on valitud teadlikult Sly \& The Family Stone, mis on üks funkmuusika tüvitekste"; itaalia muusikateadlase Enzo Restagno intervjuu Arvo ja Nora Pärdiga „on kindlasti kujunenud üheks tüvitekstiks Pärdi loomingu mõistmisel”; Veljesto mardiooper koos tüvitekstide kooriga „Ahvide Tarzan ja tüvitekstid”; „Oleme jõudumööda üritanud lõimida nii tänapäevast popmuusikat ja Eesti muusika kultuuriloo tüvitekste”; „Miks mitte õppida tulevikus koolides Eesti kirjanduse tüvitekste, illustreerides neid samasisuliste Eesti muusikateostega”; „Tobiase 1900. aastal Piibli tekstile loodud „Eks teie tea” on üks meie rahvusliku kunstmuusika tüvitekste"; ,„Laulupidu on meie tüvitekst, aga me ei toeta seda," lausus Üleoja”; „Tšehhidele on kuuest sümfoonilisest poeemist koosnev tsükkel „Minu kodumaa” ning eriti selle teine osa „Vltava” nende muusikaline tüvitekst”; „Bonnie Raitt on mulle lapsepõlvest tuttav. See on minu jaoks bluusi tüvitekst”; „Tuletan meelde Jaak Tuksami laulu „Meel unus mägede taha”. See on mu jaoks tüvitekst”...

Kunst: rahvariiete ja laulupeo kujunduse muster kui tüvitekst; eesti kunsti suunanäitavad teosed kui tüvitekstid; „Tüvitekst ei tõota koomiksis midagi head"; võimalus arhitektuuri ja kunsti seletamiseks on diskurss, „mille tüvitekstidest võiks nimetada Michel Foucault', Roland Barthes'i, Pierre Bourdieu', Henri Lefebvre'i omi"; Rein Veidemann: Eduard Wiiralt kui eesti kultuuri tüvitekst; „Kujundi tasandil võtab kahe põlvkonna ühisosa kokku kadakas, mida Eesti kunstiruumis peetakse Soosteri loomingu valitsevaks „tüvitekstiks””; „Dénes Farkas tähistab seda tüvitekstina toimivat vaimset ruumi fotokujutistega Napa galeriiruumist endast”; „Võib-olla on Veljo Kaasiku Venna maja üks Eesti 20. sajandi arhitektuuri „tüvitekste””...

\section{Järeldus A- ja B-stsenaariumist}

Mõlemas, nii välistavas kui ka kaasavas käsituses tajutakse tüviteksti kui millegi alusteksti, järgnevate nähtuste algupära, millel on tugev konstitutiivne ja regulatiivne mõju. See on mingit diskurssi - rahvuslikku, ideoloogilist, religioosset, esteetilist, filosoofilist, psühholoogilist, pedagoogilist, metoodilist, vormilist, diskursiivset, tegevuslikku - rajav tekst. Tüvitekst on nähtusi, struktuure ja tähendusi kokku koondav, edasi loov ning paljundav, mingit sisu või vormi tekitav juhis, liigi olemist deklareeriv direktiiv. Kehtestav kõne-, teksti-, diskursitegu. Tüvitekst on virtuaalne seadusekogu, stsenaarium ja „manuaal”, mis annab mõõdu ja mängureeglid, asutab ehk inaugureerib järgneva eksistentsi. See on viljastav ja toitev lähe, intra- ja intersemiootilisi ülekandeid, meediumiüleseid tõlkeid ja siirdeid ajendav tekst. Tüvitekst provotseerib jätkuvat osalust ja retseptsiooni, kas tõsist või iroonilist-paroodilist. Uusi tekste alustavana, genereerivana omandab tüvitekst teatava pühaduse aura - olgu ta piibel või tibatilluke blogisäuts -, milles ilmneb imetlus ja respekt (kui tahes kolossaalne või minimaalne) looja ja tema loodu vastu. Rajava pühaduse taustal kumab monumentaalsust ja eepilisust, isegi 
kui see on kahvatuks pleekinud. Niisiis head ingliskeelsed vasted on kindlasti seminal/core/basic text, kuigi omalt poolt võiksime välmida ka neologistliku väljendi nursery text, mis tundub tabav tõlkemetafoor tüviteksti kui seminaali ingliskeelseks tähistamiseks. Analoogiaks on looduskaitses ja metsanduses kasutatav nursery log - kõdunev sammaldunud tüvi, mis toidab uut mitmekesist taimekooslust.

Niisiis, kui ühismeelne laiali pudistav pruuk võib tihti toimuda ka muigamisi, siis kõrgstiilsem kasutus eelistab eepose kõrval eeskätt rahvuslikult või kunstiliselt kandvate tekstide ideed. Kuivõrd mõiste tähistab alustavat või algatavat, esivanema staatuses minevikulist algupära, siis on sellesse sisse kirjutatud ka teatav kaduvikunostalgia. Sageli avaldub see pre-postmodernse, suure, pihustamata narratiivi igatsuse motiivina. Nii kirjutab eetikafilosoof Margit Sutrop:

Meie kultuuri tüvitekstid, nagu „Kalevipoeg”, Tammsaare „Tõde ja õigus”, Lutsu „Kevade”, Kitzbergi „Libahunt” või Kivirähki „Rehepapp”, on tüveks, millest Eesti suur narratiiv tuge leiab. Need tekstid aitavad meil oma mõtteid korrastada ja mõista oma sügavamat olemust. (Sutrop 2014)

Teisalt visandatakse selle mõiste abil ikka tulevikku, seega ta esindab ühtlasi futuristlikku ja optimistlikku meelt, nii dekonstrueerivalt kui ka rekonstrueerivalt. Selles vaimus lausub ka Sutrop:

Mina olen vanamoodne inimene ja mulle suured narratiivid meeldivad. Ma usun ka, et Eesti suurt narratiivi ei pea hakkama välja mõtlema, seda tuleb lihtsalt edasi jutustada. [---] Tüvitekstid on selle ühise „eesti asja” sõnastamisel suureks abiks. Neid tekste tuleb aga tunda, sügavalt läbi tunnetada ning iga põlvkonna poolt omaks mõelda. Ja loomulikult peab igale uuele põlvkonnale jääma õigus teha tüvitekstidest oma valik. (Sutrop 2014)

\section{Tüvitekst kui tüvimõiste}

Strukturaalsel tasandil avaldub tüviteksti mõistel teatav ühisosa selliste mõistetega nagu risoom, hüpertekst, struktuur, arhitekst, meetod.

Artiklis „Kirjandusajalugu ja/kui kaos” määratleb Rein Veidemann (1999b) „Kalevipoega” kui tüviteksti nii essentsiaali kui ka funktsionaalina: essentsiaal kannab sünnist saadik püsivat kvaliteeti, funktsionaali tähendus muutub seostest ja kontekstidest lähtuvalt. Funktsionaalid moodustavad korreleeruvaid sõlmpunkte: „Korrelaat oleks teksti-metateksti-konteksti „kobar” mingis kirjanduslikus ajasituatsioonis" (Veidemann 1999b: 831). Seega, kuigi risoomi võrgutav termin sisenes meie humanitaariasse Gilles Deleuze’i ja Félix Guattari tutvustamise mõjul mõneti hiljem, on see mõttekujundina tuvastatav juba varem. Toetudes David Perkinsile, kirjutab Veidemann, et „nii kirjandusloolised narratiivid kui ka kirjandusfaktid keerduvad „sõlmedeks”, millede harutamine on üksnes uute „sõlmede” sidumine [---], kombineerimine” (1999b: 826). Niisiis sisaldab tüviteksti mõiste stabiilse ja lineaarse tüvelise komponendi kõrval ka ekspansiivset, tsentrist eemale laiuvat risoomset, mitte- 
lineaarset ehk kaootilist kaastähendust. Tüviteksti punguvad järelmid, Marin Laagi käsituses metatekstid, moodustavad hargneva ja sõlmleva võrgu, nii diakrooniliselt kui ka sünkrooniliselt. Risoomne fragmentaarium - pidev läbi-, üle-, juurdekirjutus - võib koonduda virtuaalseks hüpertekstiks, hõlmavaks diskursiks, mis saab omakorda tüvitekstina - ehk tüvidiskursina kui tekstikorpusena - toimima hakata, mida võib jälgida näiteks eeposte või humanistlike baastekstide geneesis (vrd ka Tiit Hennoste fragmentaariumi-nägemust). Seega on tüviteksti küsimus ühtlasi süvastruktuurne küsimus.

Struktuurid (konstitutsioonid ja mudelid), mille järgi paljundatakse virtuaalsetest invariantidest aktuaalseid variante, evivad omakorda tüvitekstilisi tunnuseid. Tüviteksti ja süvastruktuuri mõistetel, kuigi kaugel samasusest, on seega mõningane ühisosa. Sellega seostub ka arhiteksti mõiste, mis on loomult süvastruktuuri üks sünonüüme. Oma varajases traktaadis arhitekstist, mis paraku vaid sissejuhatuseks jäigi, toetub Gérard Genette (1979, 1992) Goethe- ja Hegeli-mõjulisele saksa kirjandusteadusele, kus võeti kasutusele ürgluule (Genette’i tõlkes arhiteksti) idee. Käsitust väljendab hästi eelmise sajandi esimese poole kirjandusuurija Julius Peterseni joonis (vt joonist 1, Genette 1979: 58, 1992: 54), mis mitmetes konkreetsustes on küll untsu läinud, aga põhimõtet illustreerib siiski kenasti. ${ }^{6}$

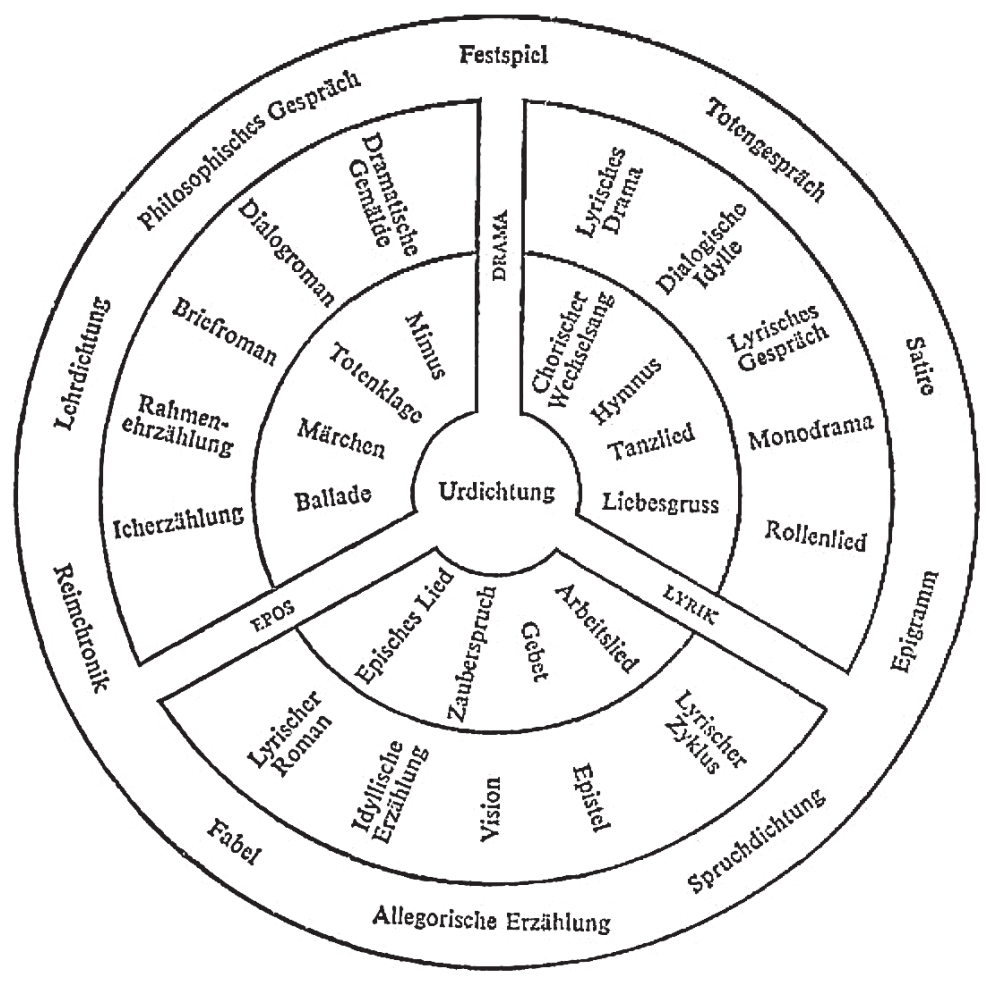

Joonis 1. Urdichtung (arhitekst) Julius Peterseni järgi.

${ }^{6}$ Aluseks on Julius Peterseni artikkel „Zur Lehre von der Dichtungsgattungen” (1925) ja monograafia „Die Wissenschaft von der Dichtung. System und Methodenlehre der Literaturwissenschaft” (1939). 
Sellest pildist tuleb hästi esile kirjanduse põhiliste avaldusviiside - lüürika, eepika, dramaatika, kaugemalt ka didaktika ja muu metatasandi - kui virtuaalsete „ürgtekstide” väljaline iseloom, mille alas kujunevad konkreetsed žanrid ja vormid. ${ }^{7}$ Žanrid on selletaolises väljakäsitluses poeetiliste väljendusviiside (n-ö diktsiooni, nagu sidumata proosakõne versus seotud luulekõne, kirjeldus, monoloog, dialoog) ja mimeetiliste ehk sisuliste teemadominantide lõikepunktid (intersektsioonid). Kui üleüldised väljendusviisid - subjektiivne sisevaatlus kui monoloogiline lüürika, objektiivne välisvaatlus kui jutustav eepika, subjektiivse ja objektiivse kokkupõrke kujutus kui dialoogiline dramaatika - on aegruumis püsivad režiimid, siis sisulised teemafookused on ajaja kultuurilooliselt muutlikud. Nii võib ka praegusel ajal selgesti jälgida kirjanduslike vormide kuhtumist ja segunemist, sellal kui sise- ja välisilma ning nendevahelise interaktsiooni kujutamine on püsiv paratamatus. Kolme klassikalist põhisektorit koondava tuuma ristib Petersen Goethe eeskujul „ürgloomeks", milles võib näha kogu sõnakunsti embrüot (sks Urdichtung, Ur-Ei). Seda lüürika, eepika ja dramaatika koondepunkti võib Genette’i järgi pidada nii kõige kandvamaks kui ka üleulatuvamaks arhitekstiks. ${ }^{8}$

Kahtlemata on niimoodi kujutatud strukturaalne arhitekst teatavas mõttes ka tüvitekst, olgugi abstraktselt võetuna ja konkreetselt kujuteldamatu, aga siiski lõputult genereeriv. Selletaoline ettekujutus ei seisa enam kaugel derridalikust „algkirja” spekulatsioonist (pr archi-écriture, tõlgitud kui ingl arche-writing, sks Urschrift), mis peaks viitama nii kõnet kui ka kirja kandvale keelelisele struktuurimeelele, mis inimese maailmasuhet ülepea võimaldab ja nägemise-väljendamise mustrid ette kirjutab (vt nt Derrida 1974: 60). Sellega oleme aga ringiga tagasi jõudnud heideggerliku nägemuse ehk olemise prao - diferentsi - vaikiva kõla juurde, mis on kahtlemata tüvitekstiks Derrida sekulaar-strukturaalsele versioonile, kuigi too astub sammu metafüüsikasse tagasi (nörritades nii mõndagi, ent võludes märksa enamaid).

Oma varasemates käsitlustes olen arhitekstilise epohhiloova ürgembrüo sünonüümina kasutanud Goethe eeskujul ka mõistet lüroeepika, mille kõige lähemaks kehastuseks on lugulaulu žanr ehk lüürilis-dramaatilis-eepiline ballaad (vt Merilai 1991a, 2003). Kasutades goethelikku võrdlust: ballaadi suhe lüroeepilisse arhiteksti on nagu puulehe suhe puusse - leht esindab metonüümiliselt puud, kehastab seda, kuid ei ole ise ei puu ega selle algupära. Sellest lähtuvalt on huvitav jälgida, kuidas Marie Underi luule kui eesti rahva ühe tüviteksti iseenda sisemiseks „tüvitekstiks” on lüroeepiline arhitekst, mida kehastab luuletaja loomingu koondepunkt, ballaadikogu „Õnnevarjutus" (vt Merilai 1991b, 2000). Ballaadipärast arhiteksti võib seega võtta kui sisemist, metoodilis-strukturaalset „tüviteksti” Underi loomingule kui rahvuslikule tüvitekstile. Sellesama teoreetilise figuuriga saab läheneda nii ballaadikoolitusega Kreutzwaldile kui ka tema eepilisele hiiglaballaadile elik

${ }^{7}$ Neid põhivälju kirjanduse põhiliikideks nimetades tuleb silmas pidada, et tegemist on abstraktsioonidega, mida ei saa liikide või eksemplaridena konkretiseerida. Igas kirjandusteoses, olgu luuletuses või romaanis, leidub üldjuhul eepilist (välismaailma kirjeldavat), lüürilist (sisetunnet sõnastavat) ja dramaatilist (sisemise ja välise suhtlust kujutavat) alget, mis mingit teost küll ühes, teises või kolmandas kallakus doseeritult võimaldavad, aga ei ole ise teos või tekst. Üldžanrid on arhitekstidena virtuaalsed, süvastruktuursed tekste võimaldavad „ettekirjutused”.

8 Kui goethelik ettekujutus viitab ürgpõhjale-algusele, siis genette'ilik taju lisab kreekalikule arche-tähendusele ka prantsuspärase $\operatorname{arc}(h e)$-kihi, mis viitab kõrguvale võlvile - kokkuvõtvale, kaarena koondavale pealisehitusele. 
lüroeepilisele kunsteeposele (vt Merilai 2015a). Analoogilise järelduse võib ekstrapoleerida kogu eesti luuleloole, kuna selles avaldub lüroeepiliste koondumiste ja hajumiste rütmiline pulss läbi ajaloo. Nii väitekiri „Eesti ballaad 1900-1940” (1991) kui ka antoloogia „Eesti ballaad. XVII-XX sajand” (2003) püüdsid seda „arhailist” mustrit kirjeldada ja esindada.

Underi näide juhtis niisiis veel ühe põneva hüpoteesini: ka loomemeetod (kui kirjutamisjuhiste kogum, kirjutaja virtuaalne „manuaal”) toimib otsekui tüvitekst (olgu jutumärkides või ilma). Selle eeskujul võib näiteks ka Tammsaare kullasoont, psühholoogilis-realistlik-sümbolistlikku aga-dialektikat pidada struktuurselt võttes tema metoodiliseks „tüvitekstiks” (vt Merilai 2015b). Funktsionaalne sarnasus ehk ühisosa on ilmne, kuid jäägem targu selle terminoloogilise paralleeli ilmestava, lahtise kasutuse juurde, mis ei taotle lähemat vastavust. Ajastu vaim - tüvitekst.

Artikli aluseks on eesti kirjanduse tüvitekstide ainekursus Tartu Ülikoolis ning konverentsil „Lausungid ja pausid: Rein Veidemann 70” 17. oktoobril 2016 Tallinna Ülikoolis peetud ettekanne „Arhitekst kui tüvitekst”.

\section{Kirjandus}

The Art of Interpretation of Classical Oriental Texts. The Second Nordic-Baltic Conference of Orientalists. Abstracts of Papers. Tartu, May 19-24, 1994. Toim Kai Vassiljeva. Tartu: Estonian Oriental Society, 1994.

Derrida, Jacques 1974. Of Grammatology. Tlk Gayatri Chakravorty Spivak. Baltimore: The Johns Hopkins University Press.

Eliot, Thomas Stearns 1997. Mis on klassik? - T. S. Eliot, Valitud esseesid. Tallinn: Hortus Litterarum, lk 254-281.

Ge n e t te, Gérard 1979. Introduction à l'architexte. Paris: Éditions du Seuil.

G e n e t t e, Gérard 1992. The Architext: An Introduction. Tlk Jane E. Lewin. Quantum Books. Berkeley-Los Angeles: Oxford: University of California Press.

Hennoste, Tiit 2011. Heroism ja eksistentsialism. Mõttevahetus: Eesti eksistentsiaalsusest. - Looming, $\mathrm{nr}$ 8, lk 1139-1148.

Hei d e g g er, Martin 1954. Bauen Wohnen Denken. - M. Heidegger, Vorträge und Aufsätze. Pfullingen: Günther Neske Verlag, lk 145-162.

Kirss, Tiina 2010. „Vana tuuletallaja”: August Kitzbergi mälestused eesti autobiograafia tüvitekstina. - Methis. Studia humaniora Estonica, nr 5/6, lk 38-53.

L a a k, Marin 2013. „Kalevipoeg” kui tüvitekst. - Keel ja Kirjandus, nr 3, lk 192 209.

Lään e mets, Märt 1995. Linnart Mäll ja Tartu orientalistika. - Keel ja Kirjandus, nr 11, lk 736-745.

Meril a i, Arne 1991a. Ballaaditeooria küsimusi. Ballaadilisus. - A. Merilai, Eesti ballaad 1900-1940. Tartu: Tartu Ülikool, lk 5-22.

Merilai, Arne 1991b. Marie Underi „Õnnevarjutus” - siseruumist arhitektuurini. - A. Merilai, Eesti ballaad 1900-1940. Tartu: Tartu Ülikool, lk 51-66.

Merilai, Arne 2000. Õnneigatsus ja hingekirik. - Marie Under, Õnnevarjutus. Kogu ballaade. Tallinn: Tänapäev, lk 71-100.

Merilai, Arne 2003. Eesti ballaad. - Eesti ballaad: Antoloogia: XVII-XX sajand. Koost A. Merilai. Tallinn: Tänapäev, lk 796-820. 
Merilai, Arne 2007. Olemise luuleline kehtestamine: Viivi Luik. - Looming - olemise kehtestamine: Viivi Luik. Toim A. Merilai. (Studia litteraria Estonica 9.) Tartu: Tartu Ülikooli Kirjastus, lk 95-104.

Merilai, Arne 2015a. Kalevipoeg: aspects of genre and authorship. - Journal of Baltic Studies, nr 46 (4), lk 497-510.

Merilai, Arne 2015b. Tammsaare aga-ometi. - Keel ja Kirjandus, nr 5, lk 297315.

Mä1l, Linnart 2000a. „Gita” kui humanistlik baastekst. - Bhagavadgītā. Tlk, komment L. Mäll. Tartu: Biblio, lk 5-16.

Mäll, Linnart 2000b. On the concept of humanistic base texts. - Sign Systems Studies, nr 28, lk 281-289.

Sutrop, Margit 2014. Eesti suur lugu ei saa läbi tüvitekstideta. - Postimees 15. VIII, lk 11.

Ude, Indrek 1988. 50. sünnipäeva ja 10. tõlkeraamatu ilmumise eel. Intervjuu Linnart Mälliga. - Tartu Riiklik Ülikool 3. VI, lk 2.

Un d u s k, Jaan 1992. Etüüdid tekstist. - Akadeemia, nr 5, lk 974-1012.

Und u sk, Jaan 1994. Rahvaluuleteksti lõppematus. Felix Oinas, soome meetod ja intertekstuaalne „Kalevipoeg”. - Felix Oinas, Surematu Kalevipoeg. (Keele ja Kirjanduse Raamatusari 1.) Tallinn: Keel ja Kirjandus, lk 147-174.

Un d u s k, Jaan 1997. Kolm võimalust kirjutada eestlaste ajalugu: Merkel - Jakobson - Hurt. - Keel ja Kirjandus, nr 11, lk 721-734; nr 12, lk 797-811.

Und usk, Jaan 2008. Eesti lugu: Henriku Liivimaa kroonika. - Eesti Päevaleht 24. X, lk 24.

Undusk, Jaan 2012. Mälukaotuskirjandus. Mälukaotuse loovast funktsioonist Karl Ristikivi ajaloolises proosas. - Looming, $\mathrm{nr}$ 10, lk 1456-1476.

Veidemann, Rein 1996. Ajavahe: Mälestusi, pihtimusi, esseid. Tallinn: Eesti Raamat.

Vei de ma n n, Rein 1999a. Laulupidu kui eesti kultuuri tüvitekst. - Sirp 17. IX, lk 3.

Veidemann, Rein 1999b. Kirjandusajalugu ja/kui kaos. - Keel ja Kirjandus, nr 12, lk 826-832.

V ei d e m an n, Rein 2000a. Laulupidu kui eesti kultuuri tüvitekst. - Eestluse elujõu kongress: 1.-2. juulil 1999. aastal Tallinnas Rahvusraamatukogus. Ettekannete ja sõnavõttude kogumik. Tallinn, lk 37-39.

Veidemann, Rein 2000b. Kultuur XXI sajandi künnisel. - Eesti uue aastatuhande lävel. Väikerahva võimalused ja valikud. Koost Ebba Rääts. Rahvusliku Arengu ja Koostöö Instituut, Akadeemia Nord. Tallinn, lk 250-258.

V ei d e m a n n, Rein 2001. Laulupidu kui eesti kultuuri tüvitekst. - R. Veidemann, Kusagil Euroopas. Tallinn: Eesti Keele Sihtasutus, lk 125-129.

Veidemann, Rein 2003. F. R. Kreutzwaldi „Kalevipoeg” kui eesti kirjanduskultuuri sakraaltekst. - Keel ja Kirjandus, nr 12, lk 891-896.

Vei de ma n n, Rein 2004. Laulupidu kui Eesti „suur jutustus”. - Muusika, nr 7/8, lk 14.

Veidemann, Rein 2006. Tuikav tekst. Artikleid ja esseid eesti kirjandusest ja kultuurist 2000-2005. Tartu: Tartu Ülikooli Kirjastus.

Veidemann, Rein 2010. Eksistentsiaalne Eesti. Käsitlusi eesti kirjandusest ja kultuurist 2005-2010. Tallinn: Tänapäev.

Vei d e m a n n, Rein 2011. Laulus sündinud, lauluga pühitsetud. - R. Veidemann, Must valgel. Valik sõnavõtte, kommentaare, arutlusi eesti elust 2002-2011. Tallinn: Eesti Keele Sihtasutus, lk 198-203. 
Veidemann, Rein 2014. Laulupidu kui Eesti kultuuri tüvitekst ja rahvakirik. - Ühesmõtlemine: „Laulu- ja tantsupeo puudutus ajas”: 24.-25. oktoober 2013, KUMU, Tallinn. Tekstide kogumik. Tallinn, lk 230-237.

\section{Isiklikud teated}

Rein Veidemanni e-kiri A. Merilaile 13. II 2017.

\section{On the semantics of tüvitekst}

Keywords: core text, base text, classic, archi-text, rhizome, structure, literature

The article discusses the synonyms, equivalents and connotations of the Estonian term tüvitekst 'core text, seminal text; lit. stem text', which in the new century has gained popularity both in Estonian criticism and in the Estonian media. The notion was first introduced in Estonia by orientalist Linnart Mäll, who studied and translated the basic works of Oriental thought, which he called humanistic base texts. These are fundamental classical texts that consolidate the past and build the future by shaping the mentality of communities and the discourses to follow. Literary scholar Jaan Undusk has referred to the Estonian national epic Kalevipoeg as a national core text building up the national psyche. By now, the term tüvitekst has become frequent in the Estonian humanities as well as in public use, largely due to the cultural articles by Rein Veidemann. There is a clear difference between the more exclusive or elitarian literary use of the term and the more inclusive or democratic one allowing for any text, written or other, to be perceived as an origin of something else or as an impulse for a discourse. A number of usage examples are brought not only from literary studies or criticism, but also from the fields of science, social issues, theatre, cinematography, music and figurative arts. The term can be applied to song festivals, official documents, products and manuals, and even to postings on social media. The semantics of the term is analysed pointing out parallels with such concepts as deep structure, rhizome, hypertext, archi-text, archi-writing and method. As metaphoric terms have semantic ramifications, the author suggests nursery text as another possible equivalent, inspired by the biological term nursery log.

Arne Merilai (b. 1961), PhD, University of Tartu, Professor and Chair of Estonian Literature,arne.merilai@ut.ee 